"Przegląd Prawa Konstytucyjnego"

------ Nr 2 (14)/2013 ------

\title{
Recenzja
}

\section{Tadeusz Zbigniew Leszczyński, Konstytucyjne podstawy stanów nadzwyczajnych w państwach batkańskich i w Turcji, Krakowskie Towarzystwo Edukacyjne sp. z o.o. - Oficyna Wydawnicza AFM, Kraków 2011, s. 240}

W ostatnich latach instytucja stanu nadzwyczajnego, po długim okresie braku zainteresowania naukowego, stała się przedmiotem intensywnych badań polskich konstytucjonalistów i politologów. Dołączył do nich także Tadeusz Zbigniew Leszczyński, autor książki Konstytucyjne podstawy stanów nadzwyczajnych w państwach bałkańskich $i w$ Turcji.

Dotychczas szczegółowo i wyczerpująco opisano ewolucję instytucji polskiego stanu nadzwyczajnego ${ }^{1}$ oraz skomentowano dotyczące jej regulacje konstytucyjne i ustawowe ${ }^{2}$. Bardzo rzadko jednak polscy badacze zajmowali się instytucją stanów nadzwyczajnych w konstytucjach innych państw3 Opracowanie T.Z. Leszczyńskiego częściowo tę lukę wypełnia.

Zob. np. monografie L. Mażewskiego, Bezpieczeństwo publiczne. Stany nadzwyczajne w Rzeczypospolitej Polskiej oraz Polskiej Rzeczypospolitej Ludowej 1918-2009. Toruń 2010 oraz Stany nadzwyczajne w Polsce w latach 1918-1989, Toruń 2006, M. Brzezińskiego, Stany nadzwyczajne w polskich konstytucjach, Warszawa 2007, a także opracowania z zakresu historii stanu nadzwyczajnego P.K. Marszałka.

2 Zob. np. monografie K. Prokopa, Stany nadzwyczajne w Konstytucji Rzeczypospolitej Polskiej, Białystok 2005 oraz W.J. Wołpiuka, Państwo wobec szczególnych zagrożeń, Warszawa 2002.

3 Tematyka ta była poruszana jedynie sporadycznie, zob. np. T. Mołdawa, Naczelne władze państwa $w$ sytuacji nadzwyczajnych zagrożeń (doświadczenia krajów Europy Zachodniej), [w:] Pokolenia. Kultura. Polityka. Księga Jubileuszowa na 65-lecie Profesora Bronisława Gołębiowskiego, Warszawa 1999, K. Prokop, Konstytucyjna regulacja stanów nadzwyczajnych we współczesnych państwach demokratycznych (wybrane problemy), [w:] Z zagadnień współczesnych społeczeństw demokratycznych, red. A. Jamróz, S. Bożyk, Białystok 2006, K. Wójtowicz, 
Autor przedstawił regulacje konstytucyjne w państwach bałkańskich i w Turcji, słusznie zwracając uwagę na szczególną rolę, jaką region ten odgrywa we współczesnej Europie (s. 18-19). Monografia obejmuje 12 państw (Albanię, Bośnię i Hercegowinę, Bułgarię, Chorwację, Czarnogórę, Grecję, Kosowo, Byłą Jugosłowiańską Republikę Macedonii, Rumunię, Serbię, Słowenię i Turcję). Każdemu z nich poświęcono osobny rozdział (w kolejności alfabetycznej), a w załącznikach przytoczono stosowne przepisy z ich konstytucji.

Do stanów nadzwyczajnych T.Z. Leszczyński zaliczył także stan wojny (s. 10) chociaż, jak sam zauważa, stan wojny „formalnie nie należy do stanów nadzwyczajnych, gdyż w przeciwieństwie do nich jest instytucją z zakresu międzynarodowego prawa publicznego, która dotyczy suwerenności, nienaruszalności granic i integralności terytorialnej państwa” (s. 237). Szkoda, iż formułując w rozdziale pierwszym założenia metodologiczne swojego opracowania, nie wyjaśnił szerzej racji, które nim kierowały. Tym bardziej, że deklaruje poszukiwanie odniesienia do ewentualnych związków konstytucyjnych podstaw stanów nadzwyczajnych w państwach bałkańskich i w Turcji z dorobkiem polskiej teorii prawa (s. 9), a w doktrynie polskiego prawa konstytucyjnego stan wojny jest postrzegany jako instytucja odrębna od stanu nadzwyczajnego ${ }^{4}$. Biorąc pod uwagę walory poznawcze publikacji, opisanie regulacji dotyczących stanu wojny w omawianych państwach jest korzystne, wydaje się jednak, iż należało bardziej jednoznacznie przytoczyć argumenty, które pozwalałyby zrozumieć ten zabieg albo zmodyfikować tytuł książki. Bez wątpienia stan wojny ,jest instytucją z zakresu międzynarodowego prawa publicznego" i „należy go uwzględniać w badaniach prowadzonych z perspektywy stosunków międzynarodowych" (s. 21), ale przytaczane w recenzowanej publikacji definicje wyraźnie odnoszą się do stanu nadzwyczajnego jako instytucji wewnętrznego prawa publicznego (s. 20-21).

Uprawnienia nadzwyczajne Prezydenta Stanów Zjednoczonych, Wrocław 1995, czy Z. Witkowski, A. Cieszyński, Instytucje stanów nadzwyczajnych w porządku prawnym Federacji Rosyjskiej (na tle genezy Konstytucji z 1993 r. i w świetle ustawodawstwa okresu 2001-2002), [w:] Sześć lat Konstytucji Rzeczypospolitej Polskiej. Doświadczenia i inspiracje, red. L. Garlicki, A. Szmyt, Warszawa 2003.

4 Zob. M. Brzeziński, Stany nadzwyczajne w polskich..., s. 61-64 i przytoczona tam literatura. 
Autor stanowczo stwierdza, iż istnieje „zastój w obszarze dociekań polskiej nauki prawa konstytucyjnego nad zagadnieniami wzajemnych oddziaływań prawa konstytucyjnego różnych państw" (s. 24). Wydaje się, iż jest to zbyt daleko idące uogólnienie. O ile teza ta jest prawdziwa w obszarze materii stanu nadzwyczajnego, to przyjęcie jej w odniesieniu do całej nauki polskiego prawa konstytucyjnego jest co najmniej dyskusyjne.

Należy zgodzić się, iż odmienność narodowych regulacji prawnych w zakresie stanu nadzwyczajnego utrudnia ich porównanie (s. 24). Z tego powodu kompleksowa analiza prawna tej instytucji powinna być prowadzona odrębnie w ramach poszczególnych systemów politycznych. Taką też formułę przyjął T.Z. Leszczyński, często czyniąc odniesienia do prawa międzynarodowego i sporadycznie porównania do rozwiązań przyjętych w Polsce.

Każdy rozdział poświęcony regulacjom w danym państwie ma podobną konstrukcję. Składa się z trzech elementów: charakterystyki podstaw ustroju państwa i struktury jego naczelnych organów, opisu konstytucyjnych podstaw stanów nadzwyczajnych oraz konkluzji sformułowanych przez Autora.

W pierwszej części poszczególnych rozdziałów Autor syntetycznie przedstawia historię ustroju omawianego państwa i jego ustawy zasadniczej, następnie opisuje system rządów, charakteryzując pokrótce parlament i organy sprawujące władzę wykonawczą. Pozwala to osadzić instytucję stanu nadzwyczajnego w konkretnych ramach ustrojowych. We wszystkich rozdziałach struktura władz ustawodawczych i wykonawczych przedstawiona jest także w formie graficznej, co zwiększa walory dydaktyczne opracowania.

Druga część każdego rozdziału usystematyzowana jest według kategorii stanów nadzwyczajnych (z uwzględnieniem stanu wojny) występujących w opisywanym państwie. Zaletą tego elementu opracowania jest między innymi to, iż Autor szeroko sięga do praktyki stosowania stanów nadzwyczajnych (zob. np. s. 37, 67, 78, 99-100, 122-123, 142-143, 154, 166-167).

Formułując konkluzje w końcowych częściach rozdziałów, T.Z. Leszczyński starał się przestawić regulacje konstytucyjne dotyczące stanów nadzwyczajnych poprzez charakterystykę ich podstawowych elementów składowych: przesłanek uzasadniających ich wprowadzenie, trybu wprowadzenia, celu zastosowania środków nadzwyczajnych, obszaru i czasu obowiązywania, skutków dla państwa i obywateli oraz trybu zniesienia stanu nadzwyczajnego. Nie zawsze było to możliwe, bowiem ustrojodawca często pomija 
niektóre z nich. W szczególności nie precyzuje przesłanek zastosowania stanu nadzwyczajnego (np. w Bułgarii, Chorwacji, Rumunii), maksymalnego czasu jego obowiązywania (np. w Bułgarii, Chorwacji, Rumunii, Słowenii) czy trybu zniesienia (np. w Bułgarii, Chorwacji, Czarnogórze czy Rumunii).

W końcowej części każdego rozdziału Autor weryfikował przewidywane skutki wprowadzenia stanu nadzwyczajnego w zakresie praw jednostki z punktu widzenia wiążącego określone państwo prawa międzynarodowego.

W zakończeniu podsumowującym całe opracowanie T.Z. Leszczyński przedstawił zbudowany na podstawie przeprowadzonej analizy model państwa „obowiązujący w badanym regionie” (s. 178), pisząc, że tak opisane „quasi-państwo jest w pełni zgodne ze stanem prawnym obowiązującym w Polsce" (s. 179). Twierdzenie to $\mathrm{z}$ dwóch powodów można uznać za dyskusyjne. Po pierwsze, wobec bardzo wielu odstępstw od przedstawionego modelu występujących w opisywanych ustrojach (sam Autor zwraca na nie uwagę - s. 177-178) reprezentatywność modelu może budzić wątpliwość. Po drugie - trudno uznać za zgodne ze stanem prawnym występującym w Polsce stwierdzenie, że „władzę ustawodawczą sprawuje jednoizbowy parlament wybierany w wyborach powszechnych na czteroletnią kadencję" (s. 178).

Badania Autora pozwoliły mu usystematyzować stany nadzwyczajne przewidziane w konstytucjach państw bałkańskich i w Turcji w cztery kategorie: stany nadzwyczajne związane z wystąpieniem klęski żywiołowej, stany nadzwyczajne związane $z$ wewnętrznym zagrożeniem funkcjonowania państwa, stany nadzwyczajne związane z zewnętrznym zagrożeniem bezpieczeństwa państwa oraz stany nadzwyczajne związane z zobowiązaniami międzynarodowymi (s. 180-181). Systematykę tę Autor również uznał za zgodną ze stanem prawnym obowiązującym w Polsce z zastrzeżeniem, że „Konstytucja Rzeczypospolitej Polskiej z dnia 2 kwietnia 1997 r. stanu wojny, w tym gdy z umów międzynarodowych wynika zobowiązanie do wspólnej obrony przeciwko agresji (art. 116), nie zalicza do stanów nadzwyczajnych” (s. 181). To oczywiście jest słuszne stwierdzenie, należy jednak pamiętać, iż w Polsce wynikające z umowy międzynarodowej zobowiązanie do wspólnej obrony przeciwko agresji jest konstytucyjną przesłanką wprowadzenia także stanu wojennego (art. 228 Konstytucji), toteż w przedstawionej klasyfikacji polski stan wojenny należałoby zaliczyć zarówno do kategorii stanów nadzwyczajnych „związanych z zewnętrznym zagrożeniem bezpie- 
czeństwa państwa”, jak i stanów nadzwyczajnych „związanych ze zobowiązaniami międzynarodowymi".

Przedstawione wyżej zastrzeżenia mają charakter wyłącznie porządkujący i w niczym nie umniejszają wartości poznawczej i dydaktycznej recenzowanej publikacji. Jest to nie tylko pierwsze w Polsce opracowanie dotyczące instytucji stanu nadzwyczajnego w konstytucjach państw tego regionu, ale także pierwsze opracowanie, które w usystematyzowany sposób przedstawia konstytucyjną regulację stanu nadzwyczajnego w tak dużej grupie państw. Jestem przekonany, że będzie ono niezwykle pomocne szczególnie osobom interesującym się polityką międzynarodową oraz szeroko rozumianym bezpieczeństwem współczesnych państw.

Krzysztof Eckhardt (Wyższa Szkoła Prawa i Administracji w Przemyślu) 